\title{
HARTMANN, Peter Claus, Französische Könige und Kaiser der Neuzeit. Von Ludwig XII. bis Napoleon III. 1498-1870
}

\section{Christophe Duhamelle}

\section{OpenEdition}

\section{Journals}

Édition électronique

URL : http://journals.openedition.org/ifha/1929

DOI : $10.4000 /$ ifha. 1929

ISSN : 2198-8943

\section{Éditeur}

IFRA - Institut franco-allemand (sciences historiques et sociales)

Référence électronique

Christophe Duhamelle, "HARTMANN, Peter Claus, Französische Könige und Kaiser der Neuzeit. Von Ludwig XII. bis Napoleon III. 1498-1870», Revue de l'IFHA [En ligne], Date de recension, mis en ligne le 01 janvier 1995, consulté le 22 septembre 2020. URL : http://journals.openedition.org/ifha/1929 ; DOI : https://doi.org/10.4000/ifha.1929

Ce document a été généré automatiquement le 22 septembre 2020.

(CIFHA 


\title{
HARTMANN, Peter Claus, Französische Könige und Kaiser der Neuzeit. Von Ludwig XII. bis Napoleon III. $1498-1870$
}

\author{
Christophe Duhamelle
}

1 Le genre biographique n'a pas connu en Allemagne la même croissance explosive qu'en France - en partie parce que la biographie telle que la conçoivent les historiens allemands est moins susceptible de trouver un large public. Pourtant, cet ouvrage collectif n'a pas d'équivalent français. Plusieurs spécialistes allemands reconnus (R. BABEL, N. BULST, A. CREMER, M. ERBE, P.C. HARTMANN, E. HINRICHS, A. KOHLER, K. MALLETKE, I. MIECK, H. SCHMIDT, H.-U. THAMER) livrent sur chacun des souverains français, du XVIe au XIXe s., des textes denses, bien informés (bibliographies souvent très complètes) et dépassant parfois le cadre utile, mais restreint, de la biographie politique. Quelles que soient par ailleurs les limites inhérentes au genre lui-même, cet ouvrage, en échappant en grande partie aux pièges de la "galerie de portraits«, est une réussite. Il témoigne par ailleurs d'une tradition des »études françaises« parmi les historiens allemands qui, même dans un domaine "classique«, est au fait des recherches récentes (le renouveau des études sur l'Etat est largement présent dans les bibliographies). On rêve de trouver l'équivalent dans l'autre sens.

2 Signalons enfin que le même éditeur a publié en 1991 un panorama comparable, et fort utile, des Empereurs (germaniques, puis autrichiens et allemands) entre 1519 et 1918. 